\title{
Gender Difference on Social Skills among Children of Haryana
}

\author{
Poonam Rani* and Bimla Dhanda \\ Department of Human Development and Family Studies, I.C. College of Home Science, \\ CCSHAU, Hisar, Haryana - 125004, India \\ *Corresponding author
}

\begin{abstract}
A B S T R A C T
\section{Keywords}

Gender, Social skills,

Communication skills,

Interpersonal skills,

Enjoyment and

competence

Article Info

Accepted:

08 August 2018

Available Online:

10 September 2018

Social skills are the skills we use every day to interact and communicate with others. They include verbal and non-verbal communication, such as speech, gesture, facial expression and body language. The study was conducted in Hisar district of Haryana state. Two areas were selected purposively i.e., rural and urban. A total of 200 children in three age groups, namely 3, 4 and 5 years were selected for the study. Age, gender and area were taken as independent variable. Social skills and social skills were taken as dependent variable. Vineland Adaptive Behavior Scale of Social Maturity (Sparrow et al., 1935) was used to determine social skills among children. Result revealed that Mean scores on social skills of boys in rural areas were higher than girls in age groups 3-5 years. There was no significant difference $(z=0.17)$ in mean score on social skills of boys and girls in rural areas on the basis of overall mean. Similarly, Mean scores of children in urban areas were high than that of children in rural areas on the basis of overall mean. The difference in mean scores on social skills of boys and girls in both locations on the basis of overall mean were nonsignificant. The mean difference in social skills was significant over the location from age group 3-5years.
\end{abstract}

\section{Introduction}

Social skill is any competence facilitating interaction and communication with others where social rules and relations are created, communicated, and changed in verbal and nonverbal ways. The process of learning these skills is called socialization. For socialization, interpersonal skills are essential to relate to one another. Interpersonal skills are the interpersonal acts a person uses to interact with others, Social skills including effective communication, social, professional ethics, problem solving, decision-making, and organizational skills are needed in adventure education to enhance the learning of children Priest and Gass (2007).

Social skills are the abilities and traits that pertain to personality, attitude, and behavior. These skills encompass a wide range of social, communication and adaptive skills (Dubrin, 2014). Children's future earning power is increasingly likely to be determined by whether or not they possess soft skills, rather than just their exam results. Full potential must include not only letters and numbers, but also the soft skills that are foundational to so 
many advantages in the life (Shonkoff and Phillips, 2010).

Social skills are the skills we use every day to interact and communicate with others. They include verbal and non-verbal communication, such as speech, gesture, facial expression and body language. A person has strong social skills if they have the knowledge of how to behave in social situations and understand both written and implied rules when communicating with others.

The importance of stimulating environment during this most plastic and impressionable stage cannot be overlooked. "Better the experience given, richer is the dividend". With the perpetual growth of the Indian economy, the importance of soft skills and technical skills in India has increased tremendously over the years.

Children are the future of the nation; they have to learn certain fundamentals such as security, association, belonging, dignity, hope, power, enjoyment and competence in the preschool classroom. These fundamentals are called "soft skills". When we focus on changes in respect to parents - rather than siblings or other persons in the household - as parents are first and foremost those capable of assisting their children to acquire non-cognitive skills Cunha et al., (2006).

\section{Objectives}

To compare the social skills among children according to age, gender and area.

\section{Materials and Methods}

The study was conducted in Hisar district of Haryana state. Two areas were selected purposively i.e., rural and urban, from urban area Hisar city and from rural area two villages namely Balsmand and Kharia were taken for collection of data. A total of 200 children in three age groups, namely, 3, 4 and 5 years were selected for the study. Age, gender and area were independent variable. Social skills were taken as dependent variable. Vineland Adaptive Behavior Scale of Social Maturity (Sparrow et al., 1935) was used to determine soft skills and social skills among children.

\section{Results and Discussion}

\section{Mean performance of children on social skills during the age of $3^{+}$to $5^{+}$years}

Mean scores on social skills of boys in rural areas were higher than girls in age groups 3-5 years. There was no significant difference $(z=$ 0.17 ) in mean score on social skills of boys and girls in rural areas on the basis of overall mean. Similarly, Mean scores of children in urban areas were high than that of children in rural areas on the basis of overall mean.

The difference in mean scores on social skills of boys and girls in both locations on the basis of overall mean were non-significant. The mean difference in social skills was significant over the location from age group 3-5years.

It was concluded that in rural areas, the mean scores of boys during the age of $3+$ and 4+ years on soft skills were low than the girls. In urban areas the mean scores of girls in the age group $3+, 4+$ and $5+$ years on soft skills were high than the boys. The mean scores of boys were low in rural and urban areas during the age of $3+, 4+$ and $5+$ years. There was no significant difference from three age groups on the basis of overall mean as this is sensitive periods in the development of the brain and behavior skills (Knudsen, 2014). There were also significant differences over locations in age group of 3+, 4+ and 5+ years. Social skills are vital in enabling an individual to have and maintain positive interactions with others (Table 1). 
Table.1 Mean performance of children on social skills during age $3^{+}$to $5^{+}$years

\begin{tabular}{|c|c|c|c|c|}
\hline Gender & \multirow[t]{2}{*}{$3^{+}$years } & \multirow[t]{2}{*}{$4^{+}$years } & \multirow[t]{2}{*}{$5^{+}$years } & \multirow[t]{2}{*}{ Overall mean } \\
\hline Rural & & & & \\
\hline Boys & $20.50 \pm 2.25$ & $19.46 \pm 5.78$ & $20.75 \pm 4.13$ & $19.83 \pm 5.15$ \\
\hline Girls & $19.94 \pm 2.68$ & $18.60 \pm 6.20$ & $19.84 \pm 6.14$ & $19.65 \pm 5.19$ \\
\hline Overall mean & $20.08 \pm 2.55$ & $19.26 \pm 5.82$ & $20.06 \pm 5.69$ & $19.73 \pm 5.15$ \\
\hline Z-test (boys vs. girls) & $0.49 \mathrm{NS}$ & $0.39 \mathrm{NS}$ & $0.47 \mathrm{NS}$ & $0.17 \mathrm{NS}$ \\
\hline \multicolumn{5}{|l|}{ Urban } \\
\hline Boys & $21.00 \pm 3.56$ & $22.60 \pm 3.14$ & $24.00 \pm 3.01$ & $22.48 \pm 3.33$ \\
\hline Girls & $20.30 \pm 6.00$ & $24.33 \pm 1.96$ & $22.20 \pm 4.11$ & $21.74 \pm 4.84$ \\
\hline Overall mean & $20.56 \pm 5.17$ & $22.97 \pm 2.99$ & $22.67 \pm 3.91$ & $22.08 \pm 4.23$ \\
\hline Z-test (boys vs. girls) & $0.41 \mathrm{NS}$ & $1.66 \mathrm{NS}$ & $1.46 \mathrm{NS}$ & $0.90 \mathrm{NS}$ \\
\hline $\mathbf{Z}$ test over location & $0.45 \mathrm{NS}$ & $3.50 * *$ & $2.24 * *$ & $7.6^{* * *}$ \\
\hline $\begin{array}{l}* * \text { Significant at } \mathrm{p}=0.01 \\
\mathrm{NS}=\text { Non significant }\end{array}$ & & $\begin{array}{l}\text { cant at } \mathrm{p}=0.05 \\
\text { indicate standar }\end{array}$ & viation & \\
\hline
\end{tabular}

Many of these skills are crucial in making and sustaining friendships. Social interactions do not always run smoothly and an individual needs to be able to implement appropriate strategies, such as conflict resolution when difficulties in interactions arise. It is also important for individuals to have 'empathy' as it allows them to respond in an understanding and caring way to how others are feeling.

\section{References}

Cunha, F., Heckman, J. J., Lance, L. and Masterov, D., 2006. Interpreting the Evidence on Life Cycle Skill Formation. In E. A. Hanushek and F. Welch (eds.) Handbook of the Economics of Education Vol.1, North Holland, Amsterdam, pp-697812.

Dubrin, A.J., 2014. Leadership: Research Findings. Practice and Skills $4^{\text {th }}$ Ed. Boston, MA: Houghton Mifflin Company, pp-312314.

Heckman, J. J., J. Stixrud, and S. Urzua (2013): "The Effects of Cognitive and
Noncognitive Abilities on Labor Market Outcomes and Social Behavior," Journal of Labor Economics, 24(3), 411-482.

Herrera, N., Zajonc, R., Wieszorkowska, G. and Cichomski, B. (2003). Beliefs about birth rank and their reflection in reality. Journal of Personality and Social Psychology, 85(1), 142-150.

Knudsen, E. I. (2004). Sensitive periods in the development of the brain and behavior. Journal of Cognitive Neuroscience, 16(1): $1412-1425$.

Paulhus, D., Trapnell, P., and Chen, D. (2009). Birth order effects on personality and achievement within families. American Psychological Society, 10(6), 482-488.

Shonkoff, J. P. and Phillips, D., 2010. From Neurons to Neighbourhoods: The Science of Early Child Development. Washington, DC: National Academy Press.

Stewart, A., Stewart, E., and Campbell, L. (2011). The relationship of psychological birth order to the family atmosphere and to personality. Journal of Individual Psychology, 57(4), 363-387.

\section{How to cite this article:}

Poonam Rani and Bimla Dhanda. 2018. Gender Difference on Social Skills among Children of Haryana. Int.J.Curr.Microbiol.App.Sci. 7(09): 1211-1213. doi: https://doi.org/10.20546/ijcmas.2018.709.144 